Громик, Юрій, і Яворський, Андрій. «Актуалізація української підляської говірки в поетичних текстах Юрія Гаврилюка». Лінгвостилістичні студії, вип. 11, 2019, с. 44-53.

Hromyk, Yurii, and Yavorskyi, Andrii. "Actualization of the Podlasie Dialect Elements in the poetic texts of Yurii Havryliuk”. Linguostylistic Studies, iss. 11, 2019, pp. 44-53.

УДК 811.161.2'282.2'34:821.162.1-1.09

https://doi.org/10.29038/2413-0923-2019-11-44-53

\title{
АКТУАЛІЗАЦІЯ УКРАЇНСЬКОЇ ПІДЛЯСЬКОЇ ГОВІРКИ В ПОЕТИЧНИХ ТЕКСТАХ ЮРІЯ ГАВРИЛЮКА
}

\author{
Юрій Громик, Андрій Яворський \\ Східноєвропейський національний університет імені Лесі Українки, \\ Луцьк, Україна
}

У статті проаналізовано особливості актуалізації української підляської говірки в поетичних текстах Юрія Гаврилюка, зокрема прокоментовано специфіку рефлексації давніх голосних, деякі відмінності у вживанні приголосних, простежено специфіку формотворення іменників, прикметників, дієслів, займенників, виявлено окремі місцеві синтаксичні явища. 3'ясовано специфіку використання автором діалектних елементів, їх місце в художній мові поета.

Ключові слова: Підляшшя, говірка, підляська говірка, діалектизм.

\section{ACTUALIZATION OF THE PODLASIE DIALECT ELEMENTS IN THE POETIC TEXTS OF YURII HAVRYLIUK Yurii Hromyk, Andrii Yavorskyi}

Lesya Ukrainka Eastern European National University, Lutsk, Ukraine

The issue of literary and dialectal language interaction is a topical issue of theoretical and practical importance in modern linguistics. One of its aspects is the use of dialects in the artistic texts that influences the dynamics of style and general literary norms through the aesthetic function of the language. The elucidation of the author's individual features of presenting the conversational language elements in the artistic texts contributes to creating a holistic picture of the tendencies in dialect-literary vocabulary interaction in general and modern trends in the development of language and literature, in particular.

The interest of the writers of Podlasie (Republic of Poland) to the folk language clearly manifested itself in the 80 s of the twentieth century. The young poets, the bearers of the Ukrainian dialects, to realize their distinctiveness from the Poles and Bielorussians began to seek self-expression in the artistic word, actualizing the features of the local dialect in their texts. Yurii Havryliuk supported the trend of creating literary works in Ukrainian using dialect elements.

The source of the research are the poetic texts from the collection of Yurii Havryliuk "In a never-ending march". The purpose of the study is to trace multilevel features of the Podlasie Ukrainian dialect in the works of Yurii Havryliuk.

At the phonetic level, the poet is disposed to preserve the specificity of reflexion of the ancient and positional variants of modern vowel phonemes, differences in consonant phonemes loading, combinatorial sound changes. At the morphological level, the most

(C) Громик Ю., Яворський А., Східноєвропейський національний університет імені Лесі Українки, 2019.

Це стаття відкритого доступу на умовах СC BY-NC 4.0 
prominent dialect phenomena are those connected with the peculiarities of the substitution of the nominal parts of language with verbs. The features of the morphemic composition of adverbs are also in the focus of the study.

Yurii Havryliuk attempted to use certain dialect elements, or imitation of the dialect speech, in his works, written in a Podlasie dialect, and he did it so skillfully that the dialect sounds like a literary language. The texts represent the North Podlasie Ukrainian dialects in all their diversity and can be successfully used as a material for the dialect studies.

Key words: Podlasie, dialect, Podlasie dialect, dialectisms.

Вступ. Юрій Гаврилюк - український письменник, публіцист, історик, головний редактор українського часопису «Над Бугом i Нарвою», громадський діяч на Підляшші в Польщі; пише твори українською мовою (давніше - підляською говіркою), а також польською мовою.

Вірші місцевою говіркою Юрій Гаврилюк почав писати 1982 року; через рік він став лауреатом конкурсу молодих творців української культури в Польщі (Яручик), а окремі його тексти надруковано було на сторінках літературно-наукового щомісячника «Наша культура» (Коженьовська-Бігун). Перша поетична книжка «В непромінаючому поході», яка якраз і містила вірші «по-свойому», «по-пудляському» (Коженьовська-Бігун), побачила світ 1986 року.

Сам Юрій Гаврилюк зізнавався: «Вірші я почав писати говіркою 3 простої причини: був це єдиний різновид української мови, який я знав. У школі мовою навчання була ж польська, учили ще нас - як у початковій школі, так і в ліцеї, котрий я закінчив - білоруської: адже всі православні у Білостоцькому воєвідстві мали бути білорусами» (Коженьовська-Бігун). Українську літературну мову поет, за його ж свідченнями, почав вивчати тільки 1982 р., коли йому до рук потрапили деякі українськомовні книжки й часопис «Наше слово»; відтоді «Ще кілька років... переважно писав вірші говіркою, хоч деяким уже сам пробував надавати “літературномовний" шліф»; «перед кінцем 1980-х рефлекс “писати по-пудляському”... зник замінила його звичка "писати по-київськи"», відповідно «пізніше, коли вже у 1989-1990 рр. - з'явилася можливість друкуватися в київських та львівських журналах і альманахах..., посилав туди вірші літературною мовою» (Коженьовська-Бігун).

Ранні вірші Юрія Гаврилюка, які написано діалектною мовою, мало знані в Україні, водночас $\epsilon$ цікавим і перспективним для досліджень явищем, бо продовжують започатковану ще в 70-х рр. й особливо активно реалізовану в кінці 80-х рр. - на початку 90-х рр. XX ст. традицію творити літературу українською підляською говіркою (або «олітературнення» говірки).

Мета дослідження - простежити в поетичних текстах Юрія Гаврилюка різнорівневі особливості української підляської говірки. Реалізація мети передбачає виконання таких завдань: а) визначити корпус використаних автором фактів діалектного мовлення; б) систематизувати засвідчені в текстах діалектні явища і прокоментувати їх із погляду 
походження; в) простежити місце й функції говіркових елементів у текстах.

Матеріал і методи дослідження. Джерельна база - тексти 3 поетичної книжки Юрія Гаврилюка «В непромінаючому поході».

Дослідження фактичного матеріалу проведене в аспекті синхронії методом лінгвістичного опису із властивими йому прийомами зовнішньої (різнорівневі діалектні явища прокоментовано у зв'язку з елементами інших мовних рівнів) та внутрішньої (зроблено інвентаризацію, диференціацію та класифікацію підляських елементів) інтерпретацій. Щоб з'ясувати специфіку фонетичних, морфологічних, лексико-семантичних явищ підляської говірки, застосовано зіставний метод (порівняння фактів діалекту та української літературної мови). Частково використано прийоми внутрішньої та зовнішньої реконструкцій для з'ясування еволюції деяких підляських лексем і словоформ.

Результати дослідження та дискусія. Як зазначено у «Вступному слові» до збірки «В непромінаючому поході», молодий поет «з потреби щирого серця» протиставляє свої тексти таким небезпечним явищам, як «національна і культурна безграмотність, безкритичне задивлення на чуже, а навіть зневажування рідного» (Гаврилюк 2). Віктор Яручик, окреслюючи проблематику віршів Юрія Гаврилюка, відзначав, що поет, народившись на Підляшші, як і всі його земляки, повсякденно змушений чути чужу для себе мову і сам користуватися нею, тому вже в ранній ліриці тема рідної мови «засигналізована» часто й чутливо: Мово наша / Батькуов і дідуов наших / Молітво наша / До руоднеї земліе / Ти як маті руодна / До сну нас колихала / Учила ти нас житі / Якімі статі людьмі (Гаврилюк 2). Водночас навіть цієї невеликої цитати достатньо для припущення, що автор усуціль пише підляською говіркою (тобто використовує ії як літературну мову). 3’ясувати, наскільки достовірна ця гіпотеза, можна шляхом аналізу засвідчених у поетичних текстах різнорівневих діалектних елементів.

Релевантна риса підляського ареалу, як і решти говорів північного наріччя, - специфічна рефлексація етимологічних голосних ${ }^{*} o,{ }^{*} e,{ }^{*}$, ${ }^{*} e,{ }^{*} i$, *у. Поезія Юрія Гаврилюка їі виразно відображає.

Аналізовані тексти ілюструють заміну етимологічного *o в закритих складах новими звуками, якість яких залежить від наголосу. У наголошеній позиції майже послідовно позначено лабіалізований дифтонг, який поет передає через сполучення літер уо: руоднеї (Гаврилюк 2), згуорок, туолькі (Гаврилюк 5), злуосно (Гаврилюк 6), стуол (Гаврилюк 7), свуой, звуон (Гаврилюк 8), муой, груом, вуойськ (Гаврилюк 9), буой (Гаврилюк 10), спокуойним (Гаврилюк 12), плодоруодне, вуон (Гаврилюк 13), сторуонкі (Гаврилюк 14), нуоч, муоцних (Гаврилюк 15), зокрема і в історично новозакритих наголошених складах: волуосьом (Гаврилюк 18), а також у закінченні *-овъ родового відмінка множини іменників: батькуов, дідуов (Гаврилюк 2), вікуов (Гаврилюк 5), матеруов (Гаврилюк 6), містуов, 
монастируов (Гаврилюк 9) та ін. Інші рефлекси наголошеного ${ }^{*}$ представлено хіба що одиничними прикладами: кольці (Гаврилюк 9), ворогув (Гаврилюк 9).

У ненаголошених новозакритих складах відповідно до *o засвідчено або [о]: заздрость (Гаврилюк 20), окно (Гаврилюк 20), зокрема послідовно в префіксі та прийменнику *одъ: одчитаємо (Гаврилюк 15), одказу (Гаврилюк 17), оддам (Гаврилюк 16), або [у]: звунніця (Гаврилюк 7), до кунця (Гаврилюк 10), в кунціе (Гаврилюк 16), зокрема без винятків у ненаголошених відмінкових флексіях та в префіксі і прийменнику *подъ: архітекторув (Гаврилюк 7), оковув, паметнікув (Гаврилюк 8), хмарув (Гаврилюк 9), дубровув (Гаврилюк 16), в (слові) улюотнум, в незламнум (желіезі) (Гаврилюк 21), в (церкві) мельницькуй (Гаврилюк 18), на почаївськуй (іконі) (Гаврилюк 18), пудляської (Гаврилюк 8), пуд плащеніцьою, пуд ногамі (Гаврилюк 5), пуд ударом (Гаврилюк 9), пудмиває (Гаврилюк 19), пуд Херонею (Гаврилюк 17), пуднюос (Гаврилюк 22), пуд тіело (Гаврилюк 12).

Лабіалізований дифтонг, графічно позначений через сполучення юо (уо), Юрій Гаврилюк ілюструє й на місці наголошеного етимологічного * $е$ в новозакритих складах, як-от: принюос (Гаврилюк 12), пуднюос (Гаврилюк 22), пронюосся (Гаврилюк 9), в юом (Гаврилюк 7) < * мь, шлуом (Гаврилюк 9) < *šelmъ (Етимологічний 6: 452), зокрема і в дериватах від давнього прислівника міри часу ${ }^{*}$ сєль: досюоль (Гаврилюк 5), зсюоль (Гаврилюк 16), так само в закінченні *-євъ родового відмінка множини іменників: серцюов (Гаврилюк 9), полюов (Гаврилюк 16). Тільки в окремих словоформах в історично новозакритих наголошених складах перед консонантом, після якого занепав зредукований переднього ряду, засвідчено й нелабіалізований дифтонг, графічно переданий через ie: каміенє (Гаврилюк 8), пломіенє (Гаврилюк 6), в пломіеньові (Гаврилюк 6). У ненаголошеній позиції в закритих складах відповідно до *е представлено монофтонги, зокрема нелабіалізований [е]: попел (Гаврилюк 12), камень (Гаврилюк 8), а в іменних закінченнях - лабіалізований [у]: воюв (Гаврилюк 15), по нашуй мові (Гаврилюк 17); один раз [у] відповідно до ${ }^{*} e$ зафіксовано й у відкритому складі: жунок (Гаврилюк 6), де, зрозуміло, його поява пов'язана з аналогією до новозакритих складів.

Юрій Гаврилюк послідовно передає й підляську специфіку рефлексації давнього *е̌, зокрема в наголошеній позиції після більшості приголосних, крім вібранта та шиплячих, позначає дифтонг через сполучення літер іе: чоловіек, сліед (Гаврилюк 2), без ціелю, передвіечна (Гаврилюк 5), всіех правовіерних, віетьор, желіеза, віечному (Гаврилюк 6), свіета, століеття, надіея (Гаврилюк 7), повіекі, собіе, в тобіе, мніе, віестнікі (Гаврилюк 8), міесець, міедну (Гаврилюк 9) та ін., так само і в іменних флексіях родового та місцевого відмінків однини: (жил) земліе (Гаврилюк 19), серце земліе (Гаврилюк 8), до земліе (Гаврилюк 2), без земліе (Гаврилюк 6), кровіе (краплі) (Гаврилюк 18), в земліе (Гаврилюк 13), 
в глибініе (Гаврилюк 13), в кунціе (Гаврилюк 16), по дніе (Гаврилюк 15), називного-знахідного відмінків множини: на каменіе (Гаврилюк 8), в країе (Гаврилюк 9), своїе (діеті) (Гаврилюк 16) та ін. Після депалаталізованих [р] i шиплячих зафіксовано наголошений варіант цього дифтонга через сполучення літер ие: застариела (Гаврилюк 5), риезаних (Гаврилюк 8), гориело, стриели, згориелі (Гаврилюк 10), риекі (Гаврилюк 15), простриелів (Гаврилюк 17), стриеламі (Гаврилюк 19), зокрема й у закінченні називного-знахідного відмінків множини іменників: богатирие (Гаврилюк 6), мечие (Гаврилюк 12). У позиції без наголосу відповідно до *ё Юрій Гаврилюк тільки після вібранта використовує $u$, позначаючи так монофтонг і результат ствердіння попереднього приголосного: рика (Гаврилюк 19), над рикою (Гаврилюк 19), ричний (Гаврилюк 19); в інших випадках, очевидно, відповідно до особливостей місцевої говірки позначено $i$ : піщаний, пісок (Гаврилюк 5), співає (Гаврилюк 6), світілась, свічок (Гаврилюк 7), цьвітут (Гаврилюк 9), на небі, сіяют (Гаврилюк 10) тощо.

Юрій Гаврилюк послідовно відтворює також підляську специфіку рефлексації давніх голосних $*_{i,}^{*} y$, зокрема відповідно до *i використовує літеру $і$ після більшості приголосних: молітво, маті, статі, людьмі, ненавісна, збереглі (Гаврилюк 2), іті, знайті, плащеніцьою, пуд ногамі, мінуле, корміт, внікаємо (Гаврилюк 5), цвінтаром (Гаврилюк 6), дурніці, лілась, мішалась, кніжок, звунніця, зімового (Гаврилюк 7), але и після шиплячих і вібранта: житі, говориті (Гаврилюк 2), зобачив, заговориті, пришла, будучиню, припадкова, не пристанувши, не оглянувшись (Гаврилюк 5), створилі, криком, істориї (Гаврилюк 6), очима, при читаньові (Гаврилюк 7) тощо. Рефлекс [и], за свідченнями Юрія Гаврилюка, в підляському ареалі представлено й на межі префіксальної та кореневої морфем на місці $*_{3}$ та $*_{i}$, які зазнали взаємної асиміляції і злилися в один звук: одийшов (Гаврилюк 12) < *отъ-ишьлъ, надийде (Гаврилюк 15) < *надъ-идьть, одийдемо (Гаврилюк 16) < *отъ-идьмъ, пудимі (Гаврилюк 9) < *nодъ-ими. Відповідно до давнього *у в основному позначено и: ми (Гаврилюк 7), ти, вибраті, скриває (Гаврилюк 5), храми, діди, богатирие (Гаврилюк 6), в глибініе (Гаврилюк 13), заглибіони (Гаврилюк 7); окрім того, у формах дієслів била (Гаврилюк 2), билі, биті (Гаврилюк 5), било, бив (Гаврилюк 15) збережено давній корінь *by(Гаврилюк 309) без розвитку його в бу-. Водночас давні звукосполучення

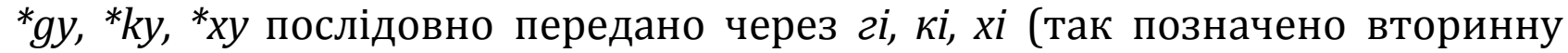
неперехідну палаталізацію задньоязикових та фарингального й появу нового [i] на місці *y): без перемогі (Гаврилюк 10), кнігі (Гаврилюк 12), Богіню (Гаврилюк 13), лєнщюгі (Гаврилюк 19), порогі (Гаврилюк 21), закіпіела (Гаврилюк 10), макі, бліскавкі (Гаврилюк 9), віестнікі, повіекі (Гаврилюк 8), хілілісь (Гаврилюк 7), епохі (Гаврилюк 5) та ін.

На місці давнього ненаголошеного *e в основах слів у післянаголошених складах позначено e: паметь (Гаврилюк 8), паметі (Гаврилюк 7), паметнікув (Гаврилюк 8), пропаметни (Гаврилюк 15), 
міесець (Гаврилюк 9), пувміесець (Гаврилюк 18); у решті позицій ілюстровано [(')a]: бражчаньом, горат, сплят (Гаврилюк 6), поняті, обняті (Гаврилюк 7), угасят (Гаврилюк 10) тощо.

Опрацьовані вірші ілюструють також специфіку рефлексації в підляській говірці ненаголошеного зредукованого *b у позиції після сонорного [р], зокрема закономірний розвиток звукосполуки *pь > [ри]: нехрищоних (Гаврилюк 6). Варіантність кореневого вокалізму в словоформах в глибініе (Гаврилюк 13), заглибіони (Гаврилюк 7), глубіну (Гаврилюк 9) відображає давні паралелі ${ }^{*} g l y b$ - та *glob- (Етимологічний 1: 523). Словоформа дубровув (Гаврилюк 16) засвідчує збереження голосного [у] без заступлення його [i], як у літературному відповідникові (Етимологічний 4: 153). Етимологічний [о] без наслідків регресивної дистантної асиміляції голосних збережено у випадках горача (Гаврилюк 2), гораче (Гаврилюк 12). Давні варіанти кореневих морфем представлено і в структурах ржа (Гаврилюк 7), ржави (Гаврилюк 18), желіезо (Гаврилюк 6).

Натомість Юрій Гаврилюк передав у текстах лабіалізацію [е] > [о] переважно перед твердим приголосним; процес цей супроводжує збереження м'якої вимови більшості передньоязикових консонантів, крім шиплячих: зельона, зельону (Гаврилюк 5), осьот (Гаврилюк 18), віетьор (Гаврилюк 6), запальоне (Гаврилюк 7), перепальони (Гаврилюк 12), всьо (Гаврилюк 10), всьой (Гаврилюк 7), але нехрищоних, значоних (Гаврилюк 6), позначони (Гаврилюк 13).

Релевантні підляські особливості в системі консонантизму передано через депалаталізацію вібранта перед [а], [у], [о]: горат (Гаврилюк 6), заострує (Гаврилюк 9), бражчит, зори (Гаврилюк 10), бражчаньом (Гаврилюк 6), царам (Гаврилюк 2), зора (Гаврилюк 16), штирохкантясти (Гаврилюк 18), також перед рефлексами *i, *е̌: говориті (Гаврилюк 2), заговориті, пришла (Гаврилюк 5), створилі, криком, істориї (Гаврилюк 6), застариела (Гаврилюк 5), риезаних (Гаврилюк 8), гориело (Гаврилюк 10), риекі (Гаврилюк 15), простриелів (Гаврилюк 17), богатирие (Гаврилюк 6), рика (Гаврилюк 19), над рикою (Гаврилюк 19), ричний (Гаврилюк 19); ствердіння шиплячих, зокрема й перед рефлексами ${ }^{*} i$, *ё: житі (Гаврилюк 2), зобачив, будучиню (Гаврилюк 5), очима, при читаньові (Гаврилюк 7), мечи (Гаврилюк 9), мечие (Гаврилюк 12); тенденцію до депалаталізації губних і передньоязикових перед ненаголошеним рефлексом *e: паметь (Гаврилюк 8), паметі (Гаврилюк 7), паметнікув (Гаврилюк 8), пропаметни (Гаврилюк 15), міесець (Гаврилюк 9), пувміесець (Гаврилюк 18); збереження історичної м'якості губних та більшості передньоязикових, крім вібранта і шиплячих, перед *i: мaті, людьмі, ненавісна, збереглі (Гаврилюк 2), іті, знайті, пуд ногамі, мінуле (Гаврилюк 5), цвінтаром (Гаврилюк 6), дурніці, кніжок, звунніця, зімового (Гаврилюк 7), а також перед рефлексами *е̌: чоловіек, сліед (Гаврилюк 2), без ціелю (Гаврилюк 5), віетьор, желіеза (Гаврилюк 6), століеття, надіея (Гаврилюк 7), повіекі (Гаврилюк 8), пісок (Гаврилюк 5), співає 
(Гаврилюк 6), світілась (Гаврилюк 7), цьвітут (Гаврилюк 9), сіяют (Гаврилюк 10); збереження м'якої вимови бокового [л] та глухого свистячого африката перед [е]: палєщь (Гаврилюк 18), землєю (Гаврилюк 5), сонцє, серцє (Гаврилюк 10); збереження історичної м'якості губних у випадках на зразок мяхка (Гаврилюк 12), мяхке (Гаврилюк 13), а також у словоформах заглибіони (Гаврилюк 7), встроміоних (Гаврилюк 3), де, мабуть, за традицією польського письма буква $i$ просто позначає м'якість попереднього консонанта; процес стягнення подовжених приголосних у випадках на зразок вміраня (Гаврилюк 10), при читаньові (Гаврилюк 7), каміенє (Гаврилюк 8), пломіенє (Гаврилюк 6), в пломіеньові (Гаврилюк 6), бражчаньом (Гаврилюк 6), мовчаньом (Гаврилюк 13), до згасіеня (Гаврилюк 14), волуосьом (Гаврилюк 18), хоча життє (Гаврилюк 16), життьом (Гаврилюк 13), тищуліеттє (Гаврилюк 15).

Лише кількома прикладами в текстах Юрія Гаврилюка відображено комбінаторні звукові зміни, зокрема регресивну суміжну асиміляцію за глухістю [бт] > [пт]: здоптаті (Гаврилюк 13), допчемо (Гаврилюк 5), подоптани (Гаврилюк 18), пор. *dъbъtati (Етимологічний 2: 110], за способом творення [зш] > [жш] без подальшої дисиміляції: бліжшимі (Гаврилюк 10), найніжши (Гаврилюк 18). Відсутність протетичного приголосного ілюструють словоформи огонь (Гаврилюк 12), огня (Гаврилюк 10), остри (Гаврилюк 13), острийом (Гаврилюк 18), заострує (Гаврилюк 9).

Юрій Гаврилюк у своїх текстах позначив і найвиразніші особливості словозміни в підляських говірках, найбільш повно - інновації фонетичного походження, що стали результатами вияву регулярних звукових процесів. Окрім тих явищ, які вже коментовано вище, можна навести прикметники чоловічного роду та співвідносні 3 ними слова 3 усіченими закінченнями -u, -i: надбужанські круг, перши сліед (Гаврилюк 7), Всевишні Літописець, шлуом гартовани, руські князю (Гаврилюк 9), дуб публяські, дуб старинни (Гаврилюк 15), остатні камень (Гаврилюк 15), пень штирохкантясти, череп риезани, осьот желіезни, пувміесець найніжши, ржави образ (Гаврилюк 18). Стягненими формами представлені прикметники та родові займенники в називному-знахідному відмінках множини: церковни бані (Гаврилюк 7), подіеї кривави, біели стіени (Гаврилюк 9), нови хвилі (Гаврилюк 19), наши князтва (Гаврилюк 15).

Виразних морфологічних архаїзмів виявлено небагато, хіба що закінчення -ох місцевого відмінка множини іменників: в грудьох (Гаврилюк 8); флексія -e в іменнику люде (Гаврилюк 8); закінчення - $\epsilon$ в субстантивах середнього роду на *-ьје: лістє (Гаврилюк 9), каміенє (Гаврилюк 8), пломіенє (Гаврилюк 6), життє (Гаврилюк 16), тищуліетте (Гаврилюк 15); повні нестягнені форми прикметників та родових займенників: людськая кров (Гаврилюк 10), малая кніжка (Гаврилюк 15), якіє прошлі (Гаврилюк 7), якіє люде (Гаврилюк 8), тиє віекі (Гаврилюк 15); форма давального-місцевого відмінків займенника 1-ї особи однини: мніе 
(Гаврилюк 8); форма родового відмінка однини предметно-особового займенника жіночого роду: єї (Гаврилюк 16); прийменникові форми без приставного [н] непрямих відмінків усіх предметно-особових займенників: в юом (Гаврилюк 7), над їм (Гаврилюк 18), до єї (Гаврилюк 16), про їх (Гаврилюк 14), із їх (Гаврилюк 16); займенник што (Гаврилюк 16); форми 3 особи на -m теперішнього часу дієслів: скриготіm, корміт (Гаврилюк 5), говорит (Гаврилюк 8), шуміт (Гаврилюк 9), сплят, горат (Гаврилюк 6), вказуют (Гаврилюк 8), цьвітут, пропадают (Гаврилюк 9).

У текстах передано чимало інновацій, що зумовлені були граматичною аналогією. Наприклад, за зразком давніх *ŭ-основ у родовому відмінку множини переоформлено більшість іменників, навіть середнього і жіночого родів: батькуов, дідуов (Гаврилюк 2), вікуов (Гаврилюк 5), архітекторув (Гаврилюк 7), оковув, паметнікув (Гаврилюк 8), ворогув, монастируов (Гаврилюк 9), хмарув (Гаврилюк 9), матеруов (Гаврилюк 6), містуов, з деревуов, серцюов (Гаврилюк 9), полюов, дубровув (Гаврилюк 16). Флексію орудного відмінка однини -ом із форм твердого різновиду поширено на структури м'якого типу відмінювання, зокрема і на іменники середнього роду на *-ьје: огньом (Гаврилюк 9), плачом, цвінтаром (Гаврилюк 6), дощом (Гаврилюк 12), острийом (Гаврилюк 18), бражчаньом (Гаврилюк 6), мовчаньом, життьом (Гаврилюк 13), волуосьом (Гаврилюк 18); подібне за характером явище в цій відмінковій позиції простежене й у формах жіночого роду: плащеніцьою (Гаврилюк 5). Більшу порівняно 3 літературним стандартом та іншими діалектами навантаженість має флексія місцевого відмінка однини -ові, яка представлена в субстантивах і чоловічого, і середнього родів, навіть у тих, що історично закінчувалися на *-ьје: по верхові (Гаврилюк 5), в верхові (Гаврилюк 18), в больові (Гаврилюк 10), в сонцьові, при читаньові (Гаврилюк 7), в пломіеньові (Гаврилюк 6). Словоформи кровіе (краплі) (Гаврилюк 18), кровєю (Гаврилюк 13) ілюструють наслідки вирівнювання за зразком субстантивів м'якого різновиду на *jā у відповідних відмінкових позиціях. За зразком чоловічого роду відмінюється іменник *цьль: без ціелю (Гаврилюк 5).

у системі ад'єктивної словозміни граматична аналогія зумовила переоформлення за зразком твердого різновиду структури могутному (Гаврилюк 21), і навпаки, за зразком історичних форм м'якої групи прикметника та порядкового числівника в словосполученнях до роуднеї земліе (Гаврилюк 2), над рикою однею (Гаврилюк 19).

За історичним м'яким зразком відмінюється займенник першого ступеня вказівності: з сіх сторуонок (Гаврилюк 15).

У системі дієвідмінювання вияв граматичної індукції можна вбачати у словоформі першої особи множини теперішнього часу зворотного дієслова боӥмосьо (Гаврилюк 5): кінцеве -о, мабуть, поширилося з форм середнього роду на зразок *боялосьо, *забулосьо, які ілюструють 
переоформлення сегмента -ся на -сьо внаслідок вирівнювання за зразком дієслів було, мало, ходило тощо.

Юрій Гаврилюк деякими штрихами позначає місцеву специфіку словотворення, зокрема відповідно до особливостей рідної говірки в присвійному значенні використовує не тільки архаїчну форму родового відмінка предметно-особового займенника жіночого роду єї (синам) (Гаврилюк 16), але й похідні, утворені шляхом поширення структури $є \ddot{~}$ суфіксом -н-: єїну глибіну (Гаврилюк 5), богатирие єїни (Гаврилюк 6). Один раз трапився підляський указівний займенник сіети «цей»: сіети стіени (Гаврилюк 13). У текстах ілюстровано також деякі місцеві прислівникові деривати, як-от: досюоль (Гаврилюк 5), зсюоль (Гаврилюк 16), знова, штораз (Гаврилюк 15), зокрема форми вищого ступеня порівняння на зразок сільніей (Гаврилюк 15).

У текстах Юрія Гаврилюка відтворено окремі явища синтаксичного рівня. Як свідчить поет, у підляському ареалі збережено прийменники $o$, послі: переконає о туом (Гаврилюк 19), тіело послі бою (Гаврилюк 12); при однорідних членах речення та між частинами складносурядного речення вживано сполучник алі-варіант загальновживаного але: Не туолькі вода / Алі й час... / нас пудмиває (Гаврилюк 19); у підрядних реченнях представлено сполучне слово што: Вспомінає тищуліеттє / Што мінуло й не вернеться (Гаврилюк 15), сполучники коб, штоб: Пришла пора / Коб вибраті дорогу (Гаврилюк 5), Входілі ми сюди / Штоб поняті (Гаврилюк 7), сполучне слово пока і його еквівалент - сполучник-полонізм аж: Не сягне же ворог лютий... / Пока сталь в руках бліскуча (Гаврилюк 9), Тут ми будем... / Аж про нас успомніт Маті-Русь (Гаврилюк 16).

Висновки та перспективи досліджень. Аналізовані художні тексти переконливо засвідчили, що Юрій Гаврилюк у віршах повно й системно відобразив фонетику підляської говірки, зокрема відтворив рефлексацію давніх і позиційне варіювання сучасних голосних, відмінності у вживанні окремих приголосних, деякі наслідки комбінаторних звукових змін. На морфологічному рівні ілюстровано релевантні явища словозміни іменників, прикметників, дієслів, займенників. Передано специфіку в уживанні прийменників, а також у використанні сполучників і сполучних слів у деяких синтаксичних конструкціях.

Аналізовані поетичні тексти всуціль написано підляською говіркою. Вони настільки повно репрезентують мову мешканців Північного Підляшшя, що можуть бути кваліфіковані як надійне діалектографічне джерело.

Перспективу дослідження вбачаємо в потребі проаналізувати інші, зокрема й публіцистичні, тексти Юрія Гаврилюка.

\section{Список використаної літератури}

Гаврилюк, Юрій. В непромінаючому поході. Біельск, 1986.

Етимологічний словник української мови, під ред. О. С. Мельничука. В 7 т. Київ: Наукова думка, 1982-2012. 
Коженьовська-Бігун, Анна. «Інтерв’ю з Юрієм Гаврилюком». Наше слово, №32, 5 серпня 2012.

Яручик, Віктор. «Проблематика творчості поета з Підляшшя Юрія Гаврилюка». Над Бугом і Нарвою, № 5 (69), 2003, с. 42-5.

\section{References}

Havryliuk, Yurii. V neprominaiuchomu pokhodi. Bielsk, 1986.

Etymolohichnyi slovnyk ukrainskoi movy, edited by O. S. Melnychuk. 7 vols. Kyiv: Naukova dumka, 1982-2012.

Kozhenovska-Bihun, Anna. "Interviu z Yuriiem Havryliukom". Nashe slovo, no. 32, 5 Aug. 2012. Yaruchyk, Viktor. "Problematyka tvorchosti poeta z Pidliashshia Yuriia Havryliuka". Nad Buhom i Narvoiu, no. 5 (69), 2003, pp. 42-5.

Стаття надійшла до редколегії 22.07.2019 